\title{
ENTREPRENEUR
}

Jurnal Bisnis Manajemen Dan Kewirausahaan

Program Studi Manajemen Fakultas Ekonomika dan Bisnis Universitas Majalengka

Published every January and July e-ISSN : 2776-2483, p-ISSN: 2723-1941

Available online http://ejournal.unma.ac.id/index.php/entrepreneur

\section{Pengaruh Motivasi Dan Kompetensi Terhadap Kinerja Perawat Di Instalasi Paviliun Tandang Pada Rumah Sakit Umum Daerah Kabupaten Sumedang}

\author{
Nining Kurniasih \\ Sekolah Tinggi Ilmu Ekonomi Sebelas April Sumedang \\ e-mail : anienk73@gmail.com
}

\begin{abstract}
The findings of this study prove all the hypotheses of this research, namely that there is an influence of work motivation and competence, either simultaneously or partially. The influence arising from the results of the study shows a positive direction, which means that better work motivation and good competence will improve the performance of nurses. Nurse motivation is a form of willingness to strive to achieve organizational goals by paying attention to efforts to satisfy several needs, as well as efforts to to improve and shape the knowledge, attitudes and behavior of employees so that these employees voluntarily try to work cooperatively with other employees to improve their performance.

The effect of work motivation on the performance of nurses, to see if there is an influence between the motivational variables and the performance of nurses, the thing that needs to be done is to determine the hypothesis, based on the calculation results, $\mathrm{HO}$ is rejected and $\mathrm{HI}$ is accepted. This means that there is an influence between the motivation and performance of nurses. while the magnitude of the influence of motivation on the performance of nurses means that motivation increases, then the performance will increase.

The effect of competence on the performance of nurses, the results of the calculation of $H O$ are rejected and $H 1$ is accepted. This means that there is an influence between the competence and performance of nurses. To see the effect of motivation and competence on the performance of nurses simultaneously (combined), the magnitude of $R$ Square can be used to see the magnitude of the influence of motivation and competence on the performance of nurses simultaneously or simultaneously. The magnitude of the influence of motivation and competence on the performance of nurses is jointly influenced by other factors, namely, training, compensation and others.

The results of the calculation of the correlation between the variables studied using the SPSS software assistance program, it is known that the correlation value between motivation and competence variables shows that the relationship between variables is very strong. and the correlation of the two variables is significant, from the results of the path coefficient calculations obtained, it can be seen the magnitude of the influence of the hypothesized variables. variables outside the research variables affect the performance of nurses.
\end{abstract}

Keywords: Motivation; Competence; Performance of Nurses 


\section{ENTREPRENEUR}

\section{Jurnal Bisnis Manajemen Dan Kewirausahaan}

Program Studi Manajemen Fakultas Ekonomika dan Bisnis Universitas Majalengka

Published every January and July e-ISSN : 2776-2483, p-ISSN: 2723-1941

Available online http://ejournal.unma.ac.id/index.php/entrepreneur

\section{PENDAHULUAN}

Kualitas Sumber Daya Manusia (SDM) merupakan salah satu faktor untuk meningkatkan kinerja suatu organisasi atau instansi. Oleh karena itu, diperlukan sumber daya manusia yang mempunyai kompetensi tinggi karena kompetensi akan dapat mendukung peningkatan prestasi kinerja pegawai. Selama ini banyak instansi pemerintah yang belum mempunyai pegawai dengan kompetensi yang memadai. Peranan dan kedudukan Pegawai Negeri Sipil (PNS) sangat penting dan menentukan karena pegawai negeri merupakan unsur aparatur negara dalam menyelenggarakan tugas-tugas pemerintahan dan pembangunan dalam rangka mencapai tujuan nasional. Anggaran Negara yang dibelanjakan untuk kepentingan pegawai negeri dari tahun ke tahun mengalami kenaikan, namun hal tersebut belum diimbangi dengan peningkatan profesionalisme dan integritas yang tinggi bagi komunitas Pegawai Negeri Sipil.

Hal yang terpenting dalam menentukan kinerja yang baik adalah memiliki sumber daya manusia yang berkualitas agar dapat mewujudkan tujuan dari perusahaan. Wibowo (2007:79) menjelaskan kinerja merupakan suatu proses tentang bagaimana pekerjaan berlangsung untuk mencapai hasil kerja. Rumah Sakit Umum Daerah Kabupaten Sumedang merupakan satusatunya Rumah sakit milik Pemerintah yang dituntut untuk melaksanakan upaya pelayanan kesehatan secara efektif dan efisien. Rumah Sakit Umum Daerah Kabupaten Sumedang harus memperbaiki kinerja setiap karyawannya agar motto “ CERMAT" yaitu Cepat, Efisien, Ramah, Mutu, Aman, Tertib dapat terwujud. Adanya dukungan motivasi baik yang diberikan dari pimpinan maupun rekan kerja rumah sakit itu sendiri dan kompetensi yang tinggi, membuat proses manajemen organisasi dapat berjalan dengan baik, khususunya dalam meningkatkan kinerja karyawan. Paviliun Tandang salah satu unit Rawat Inap berada di antai II dan III, jumlah pasilitas rawat inap sebanyak 20 bed yang terdiri dari fasilitas tempat tidur, ruang AC, kamar mandi, kulkas, set sofa bed, televise, telepon line, oksigen dll, tentunya fasilitas yang dimiliki oleh Paviliun tandang merupakan salah satu faktor yang dapat menunjang kinerja perawat, apabila kinerja perawat di Paviliun Tandang meningkat maka tujuan organisasi akan tercapai. Berikut data tingkat efisiensi dan mutu pengelolaan kinerja Paviliun Tandang

Tabel. 1 Tingkat Efisiensi dan mutu pengelolaan kinerja Paviliun Tandang Sumedang

\begin{tabular}{ccc}
\hline \multirow{2}{*}{ Uraian } & \multicolumn{2}{c}{ Tahun } \\
\cline { 2 - 3 } & $\mathbf{2 0 1 9}$ & $\mathbf{2 0 2 0}$ \\
\hline BOR & 74,67 & 89,80 \\
\hline LOS & 3,17 & 3,34 \\
\hline TOI & 1,06 & 0,40 \\
\hline BTO & 87,33 & 92,71 \\
\hline GDR & 0,27 & 1,13 \\
\hline NDR & 0,11 & 0,72 \\
\hline
\end{tabular}

Sumber : data dilah tahun 2020 


\section{ENTREPRENEUR \\ Jurnal Bisnis Manajemen Dan Kewirausahaan \\ Program Studi Manajemen Fakultas Ekonomika dan Bisnis Universitas Majalengka \\ Published every January and July e-ISSN : 2776-2483, p-ISSN: 2723-1941 \\ Available online http://ejournal.unma.ac.id/index.php/entrepreneur}

Dari data di atas terlihat bahwa pengelolaan kinerja Paviliun Tandang dilihat tahun 2019 meningkat dibandingkan dengan tahun 2020 dengan demikian efisiensi dan mutu pengelolaan kinerja sudah optimal, pada BOR (Angka penggunaan tempat tidur) pada indikator ini memberikan gambaran tinggi rendahnya pemanfaatan tempat tidur rumah sakit, AVLOS (rata-rata lamanya pasien dirawat) artinya disamping memberikan gambaran tingakt efisiensi, juga dapat memberikan gambaran mutu pelayanan, TOI (Tenggang perputaran tempat tidur) yaitu rata-rata hari dimana tempat tidur tidak ditempati dari telah diisi kesaat terisi berikutnya, BTO (Angka perputaran tempat tidur) yaitu frekuensi pemakaian tempat tidur pada satu periode, berapa kali tempat tidur dipakai dalam satu satuan waktu tertentu, GDR merupakan angka kematian umum untuk setiap 1000 penderita keluar dan NDR merupakan angka kematian 48 jam setelah dirawat untuk tiap-tiap 1000 penderita keluar. Ini merupakan gambaran mutu pelayanan di Rumah Sakit Umum Daerah Kabupaten Sumedang. Tetapi ada permasalahan-permasalahan kinerja perawat yang harus diperbaiki sehingga kinerja lebih meningkat lagi. Masalah kinerja karyawan apabila tidak ditangani dengan baik akan dapat menyebabkan terganggunya kinerja RSU Daerah Sumedang secara keseluruhan. Permasalahanmya yaitu adanya hubungan personal yang kurang baik antara satu karyawan dengan karyawan yang lainnya berdampak pada kinerja karyawan pada RSU Daerah Sumedang tidak optimal. Hubungan antar personal antar karyawan tersebut merupakan salah satu indikator motivasi. Karyawan pada Rumah Sakit Umum Daerah Sumedang kurang memiliki kemampuan, keterampilan, dan pengetahuan. Hal ini disebabkan karena masih banyak karyawan yang memiliki pendidikan terakhir SMA atau SPK dan dari D3 Keperawatan. Hal tersebut dapat menimbulkan kompetensi yang kurang dan akan menyebabkan kinerja dalam Rumah sakit tersebut menjadi rendah. Masih adanya perawat yang mangkir dari tugas tanpa alasan yang jelas, ada kecenderungan perawat malas-malsan dalam menangani pasein dan, menunggu perintah atasan.

Berdasarkan uraian tersebut, penulis merasa tertarik untuk melakukan penelitian, penulis mengangkat judul "Pengaruh Motivasi dan Kompetensi Terhadap Kinerja Perawat (Studi kasus di Instalasi Paviliun Tandang pada Rumah Sakit Umum Daerah Kabupaten Sumedang)"

\section{Identifikasi Masalah}

Berdasarkan permasalahan yang dipaparkan di latar belakang, maka dapat diidentifikasikan masalah sebagai berikut :

1. Masih ada perawat yang mangkir dari tugas tanpa alasan yang jelas

2. Masih ada perawat yang kurang tanggap terhadap keluhan pasien

3. Kurang baiknya hubungan personal antar perawat

4. Masih kurangnya kemampuan perawat dalam menangani pasien

\section{Rumusan Masalah}

Berdasarkan latar belakang diatas, penulis mencoba merumuskan permasalahan tentang :

1. Bagaimanakah Pengaruh Motivasi terhadap Kinerja Perawat di Instalasi Paviliun Tandang pada Rumah Sakit Umum Daerah Kabupaten Sumedang

2. Bagaimana Pengaruh Kompetensi terhadap Kinerja Perawat di Instalasi Paviliun Tandang pada Rumah Sakit Umum Daerah Kabupaten Sumedang. 


\section{ENTREPRENEUR \\ Jurnal Bisnis Manajemen Dan Kewirausahaan \\ Program Studi Manajemen Fakultas Ekonomika dan Bisnis Universitas Majalengka \\ Published every January and July e-ISSN : 2776-2483, p-ISSN: 2723-1941 \\ Available online http://ejournal.unma.ac.id/index.php/entrepreneur}

3. Bagaimana Pengaruh Motivasi dan Kompetensi terhadap kinerja perawat di Instalasi Paviliun Tandang di Rumah Sakit Umum Daerah Kabupaten Sumedang .

\section{Tujuan Penelitian}

1. Untuk mengetahui Pengaruh Motivasi terhadap Kinerja Perawat di pada Di Rumah Sakit Umum Daerah Kabupaten Sumedang .

2. Untuk mengetahui Pengaruh Kompetensi terhadap Kinerja perawat di Instalasi Paviliun Tandang Rumah Sakit Umum Daerah Kabupaten Sumedang. .

3. Untuk mengetahui Pengaruh Motivasi dan Kompetensi terhadap kinerja perawat di Instalasi Paviliun Tandang Rumah Sakit Umum Daerah Kabupaten Sumedang .

\section{KERANGKA PEMIKIRAN DAN HIPOTESIS}

Motivasi kerja adalah suatu perangsang keinginan dan daya gerak yang menyebabkan seseorang bersemangat dalam bekerja karena terpenuhi kebutuhannya. Pengertian motivasi menurut Robbins (2015) mendefinisikan “ Motivasi merupakan kesediaan untuk mengeluarkan tingkat upaya yang tinggi untuk tujuan organisasi yang dikondisikan oleh kemampuan upaya itu dalam memenuhi beberapa kebutuhan individual. Sedangkan Luthans (2006) menyatakan bahwa motivasi merupakan proses yang dimulai dengan defisiensi fisiologis atau psikologis yang menggerakan perilaku atau dorongan yang ditujukan untuk tujuan atau insentif. Dengan demikian motivasi kerja berarti dorongan atau kehendak seseorang untuk melaksanakan tindakan atau kegiatan dalam lingkup tugastugas yang merupakan pekerjaan atau jabatan di lingkungan sebuah organisasi.

\section{a. Faktor-Faktor yang Mempengaruhi Motivasi Kerja \\ Menurut Herzberg (dalam Novitasari,} 2020:35) mengembangkan teori hierarki kcbutuhan Maslow menjadi teori dua factor tentang motivasi. Dua faktor itu dinamakan faktor pemuas (motivation factor) yang disebut dengan satisfier atau intrinsic motivation dan faktor pemelihara (maintenance factor) yang disebut dengan disatisfier atau extrinsic motivation. Faktor pemuas yang disebut juga motivator yang merupakan faktor pendorong seseorang untuk berprestasi yang bersumber dari dalam diri seseorang tersebut (kondisi intrinsik) antara lain: 1) Prestasi yang diraih (achievement) 2) Pengakuan orang lain (recognition) 3) Tanggungjawab (responsibility) 4) Peluang untuk maju (advancement) 5) Kepuasan kerja itu sendiri (the work it self) 6) Kemungkinan pengembangan karir (the possibility of growth).

Faktor pemelihara (maintenance factor) disebut juga hygiene factor merupakan faktor yang berkaitan dengan pemenuhan kebutuhan untuk memelihara keberadaan karyawan sebagai manusia, pemeliharaan ketentraman dan kesehatan. Faktor ini juga disebut dissatisfier (sumber ketidakpuasan) yang merupakan tempat pemenuhan kebutuhan tingkat rendah yang dikualifikasikan ke dalam faktor ekstrinsik, meliputi : kompensasi, keamanan dan keselamatan kerja, kondisi kerja, status, prosedur perusahaan dan mutu dari supevisi teknis dari hubungan interpersonal di antara teman sejawat, dengan atasan, dan dengan bawahan. 


\section{ENTREPRENEUR \\ Jurnal Bisnis Manajemen Dan Kewirausahaan \\ Program Studi Manajemen Fakultas Ekonomika dan Bisnis Universitas Majalengka \\ Published every January and July e-ISSN : 2776-2483, p-ISSN: 2723-1941 \\ Available online http://ejournal.unma.ac.id/index.php/entrepreneur}

\section{b. Konsep Kompetensi}

Kompetensi adalah suatu kemampuan untuk melaksanakan atau melakukan suatu pekerjaan atau tugas yang dilandasi atas keterampilandan pengetahuan serta didukung oleh sikap kerja yang dituntut olehpekerjaan tersebut. Kompetensi sebagai kemampuan seseorang untukmenghasilkan pada tingkat yang memuaskan di tempat kerja, jugamenunjukkan karakteristik pengetahuan dan keterampilan yang dimilikiatau dibutuhkan oleh setiap individu yang memampukan mereka untukmelakukan tugas dan tanggung jawab mereka secara efektif danmeningkatkan standar kualitas professional dalam pekerjaan. Ada beberapa definisi kompetensi diantaranya menurut Marwansyah (2014 : 35) : ' Kompetensi dapat didefinisikan sebagai pengetahuan, keterampilan, kemampuan dan atau karakteristik lainnya yang dimiliki sumber daya manusia dan yang diperlukan untuk menajalankan sebuah aktivitas dalam sebuah konteks bisnis tertentu". Kompetensi berdasarkan Peraturan Pemerintah Nomor 100 Tahun 2000, adalah kemampuan dan karakteristik yang dimiliki oleh seorang PNS berupa pengetahuan, keterampilan dan atau sikap perilaku yang diperlukan dalam pelaksanaan tugas jabatannya. Spencer dan Spencer (dalam Palan, 2007:6), menguraikan lima karakteristik yang membentuk kompetensi, sebagai berikut:

1. Pengetahuan; merujuk pada informasi dan hasil pembelajaran.

2. Keterampilan; merujuk pada kemampuan seseorang untuk melakukan suatu kegiatan.

3. Konsep diri dan nilai-nilai; merujuk pada sikap, nilai-nilai dan citra diri seseorang, seperti kepercayaan seseorang bahwa dia bisa berhasil dalam suatu situasi.
4. Karakteristik pribadi; merujuk pada karakteristik fisik dan konsistensi tanggapan terhadap situasi atau informasi, seperti pengendalian diri dan kemampuan untuk tetap tenang dibawah tekanan.

5. Motif; merupakan emosi, hasrat, kebutuhan psikologis atau dorongandorongan lain yang memicu tindakan.

Karakteristik kompetensi dibedakan berdasarkan pada tingkat mana kompetensi tersebut dapat diajarkan. Cara yang paling hemat bagi organisasi untuk memiliki kompetensi ini adalah melalui proses seleksi karakter. Berikut ini akan diuraikan secara rinci masing-masing karakteristik kompetensi sebagaimana yang dikemukakan oleh Spencer dan Spencer dalam Palan (2007 : 25), sebagai berikut :

\section{Pengetahuan}

Pengetahuan pegawai turut menentukan berhasil tidaknya pelaksanaan tugas yang dibebankan kepadanya, pegawai yang mempunyai pengetahuan yang cukup akan meningkatkan efisiensi perusahaan. Namun bagi pegawai yang belum mempunyai pengetahuan cukup, maka akan bekerja tersendat-sendat.

Menurut Spencer dan Spencer, dikutip oleh Sutoto (2014), cluster pengetahuan meliputi kompetensi analytical thinking (AT) conceptual thinking (CT), technical/professional/managerial expertise (EXP)

a. Analytical thinking (AT) adalah kemampuan memahami situasi dengan merincinya menjadi bagian-bagian kecil, atau melihat implikasi sebuah situasi secara rinci. Pada intinya, kompetensi ini memungkinkan seseorang berpikir secara analitis atau sistematis terhadap sesuatu yang kompleks. 


\section{ENTREPRENEUR}

\section{Jurnal Bisnis Manajemen Dan Kewirausahaan}

Program Studi Manajemen Fakultas Ekonomika dan Bisnis Universitas Majalengka

Published every January and July e-ISSN : 2776-2483, p-ISSN: 2723-1941

Available online http://ejournal.unma.ac.id/index.php/entrepreneur

b. Conceptual thinking (CT) adalah memahami sebuah situasi atau masalah dengan menempatkan setiap bagian menjadi satu kesatuan untuk mendapatkan gambar yang lebih besar. Termasuk kemampuan mengidentifikasi pola atau hubungan antar situasi yang tidak secara jelas terkait; mengidentifikasi isu mendasar atau kunci dalam situasi yang kompleks. CT bersifat kreatif, konsepsional, atau induktif.

c. Expertise (EXP) termasuk pengetahuan terkait pada pekerjaan (bisa teknikal, profesional, atau manajerial), dan juga motivasi untuk memperluas, memanfaatkan, dan mendistribusikan pengetahuan tersebut.

\section{Keterampilan}

Pegawai yang mempunyai kemampuan kerja yang baik, maka akan mempercepat pencapaian tujuan organisasi, sebaliknya pegawai yang tidak terampil. akan memperlambat tujuan organisasi. Untuk pegawai pegawai baru atau pegawai dengan tugas baru diperlukan tambahan kemampuan guna pelaksanaan tugas-tugas yang dibebankan kepadanya.

Menurut Spencer dan Spencer, dikutip oleh Sutoto (2014), cluster keterampilan meliputi kompetensi concern for order (CO), initiative (INT), impact and influence (IMP), dan information seeking (INFO).

a. Concern for order (CO) merupakan dorongan dalam diri seseorang untuk mengurangi ketidakpastian di lingkungan sekitarnya, khususnya berkaitan dengan pengaturan kerja, instruksi, informasi dan data.

b. Initiative (INT) merupakan dorongan bertindak untuk melebihi yang dibutuhkan atau yang dituntut dari pekerjaan, melakukan sesuatu tanpa menunggu perintah lebih dahulu.
Tindakan ini dilakukan untuk memperbaiki atau meningkatkan hasil pekerjaan atau menghindari timbulnya masalah atau menciptakan peluang baru.

c. Impact and influence(IMP) merupakan tindakan membujuk, meyakinkan, mempengaruhi atau mengesankan sehingga orang lain mau mendukung agendanya. d. Information seeking (INFO) merupakan besarnya usaha tambahan yang dikeluarkan untuk mengumpulkan informasi lebih banyak.

\section{Konsep Diri dan Nilai-nilai}

Konsep diri dan nilai-nilai merujuk pada sikap. Disamping pengetahuan dan keterampilan pegawai, hal yang perlu diperhatikan adalah sikap atau perilaku kerja pegawai. Apabila pegawai mempunyai sifat yang mendukung pencapaian tujuan organisasi, maka secara otomatis segala tugas yang dibebankan kepadanya akan dilaksanakan dengan sebaik-baiknya.

Menurut Spencer dan Spencer dikutip oleh Sutoto (2014),cluster ini mencakup kompetensi developing others (DEV), directiveness:assertiveness and use of positional power (DIR), teamwork andcooperation (TW), team leadership (TL), interpersonal understanding (IU), dan customer service orientation (CSO).

a. Developing others (DEV) adalah versi khusus dari impact andinfluence, berupa kemauan untuk mengembangkan orang lain. Esensi dari kompetensi ini terletak pada kemauan serius untuk mengembangkan orang lain dan dampaknya ketimbang sebuah peranformal. Bisa dengan mengirim orang ke program training secara rutinuntuk memenuhi kebutuhan pekerjaan dan perusahaan. Cara lain adalah dengan bekerja untuk 


\section{ENTREPRENEUR}

\section{Jurnal Bisnis Manajemen Dan Kewirausahaan}

Program Studi Manajemen Fakultas Ekonomika dan Bisnis Universitas Majalengka

Published every January and July e-ISSN : 2776-2483, p-ISSN: 2723-1941

Available online http://ejournal.unma.ac.id/index.php/entrepreneur

mengembangkan para kolega, klien, bahkan atasan.

b. Directiveness assertiveness and use of positional power (DIR) mencerminkan kemauan untuk membuat orang lain selaras dengan keinginannya. Di sini sang pemimpin menceritakan apa yang harus dilakukan.

c. Teamwork and cooperation (TW) berarti kemauan sungguh-sungguh untuk bekerja secara kooperatif dengan pihak lain, menjadi bagian sebuah tim, bekerja bersama sehingga menjadi lebih kompetitif.

d. Team leadership(TL) adalah kemauan untuk berperan sebagai pemimpin tim atau kelompok lain. Jadi berkaitan dengan keinginan untuk memimpin orang lain. TL lazimnya terlihat dalam posisi otoritasformal.

e. Interpersonal understanding(IU) merupakan kemampuan untuk memahami dan mendengarkan hal-hal yang tidak diungkapkan dengan perkataan, bisa berupa pemahaman atas perasaan, keinginan atau pemikiran orang lain.

f. Customer service orientation (CSO) merupakan keinginan untuk menolong atau melayani pelanggan atau orang lain. Pelanggan adalah pelanggan aktual atau pelanggan akhir dari organisasi yang sama.

\section{Karakteristik Pribadi}

Karakteristik pribadi merupakan cerminan bagaimana seorang pegawai mampu/tidak mampu melakukan suatu aktivitas dan tugas secara mudah/sulit dan sukses/tidak pernah sukses. Menurut Spencer danSpencer dikutip oleh Sutoto (2014), cluster ini mencakup kompetensi self control (SCT), self confidence (SCF), flexibility (FLX), dan organizational commitment (OC). a. Self control (SCT) merupakan kemampuan untuk mengendalikan emosi diri sehingga mencegah untuk melakukan tindakan-tindakan yang negatif pada saat ada cobaan, khususnya ketika menghadapi tantangan atau penolakan dari orang lain atau pada saat bekerja dibawah tekanan.

b. Self confidence (SCF) merupakan keyakinan seseorang pada kemampuan diri sendiri untuk menyelesaikan suatu tugas atau tantangan.

c. Flexibility (FLX) merupakan kemampuan menyesuaikan diri dan bekerja secara efektif pada berbagai situasi, dengan berbagai rekan atau kelompok yang berbeda; kemampuan untuk memahami dan menghargai perbedaan dan pandangan yang bertentangan atas suatu isu.

d. Organizational commitment (OC) merupakan kemampuan dan kemauan seseorang untuk mengaitkan apa yang diperbuat dengan kebutuhan, prioritas dan tujuan organisasi; berbuat sesuatu untuk mempromosikan tujuan organisasi atau untuk memenuhi kebutuhan organisasi; dan menempatkan misi organisasi diatas keinginan diri sendiri atau peran profesionalnya.

\section{Motif}

Motif adalah kekuatan pendorong yang akan mewujudkan suatu perilaku guna mencapai tujuan kepuasan dirinya. Menurut Spencer dan Spencer, dikutip oleh Sutoto (2014), Cluster ini mencakup organizational awareness (OA), relationship building $(\mathrm{RB})$, danachievement orientation $(\mathrm{ACH})$

a. Organizational awareness (OA) merupakan kemampuan untuk memahami hubungan kekuasan atau posisi dalam organisasi. 


\section{ENTREPRENEUR \\ Jurnal Bisnis Manajemen Dan Kewirausahaan \\ Program Studi Manajemen Fakultas Ekonomika dan Bisnis Universitas Majalengka \\ Published every January and July e-ISSN : 2776-2483, p-ISSN: 2723-1941 \\ Available online http://ejournal.unma.ac.id/index.php/entrepreneur}

b. Relationship building (RB) merupakan besarnya usaha untuk menjalin dan membina hubungan sosial atau jaringan hubungan sosial agar tetap hangat dan akrab.

c. Achievement orientation (ACH) merupakan derajat kepedulian seorang pegawai terhadap pekerjaannya, sehingga terdorong berusaha untuk bekerja lebih baik atau di atas merupakan derajat kepedulian seorang pegawai terhadap standar.

\section{Kinerja Pegawai}

Secara etimologi, kinerja berasal dari kata performance.Performance berasal dari kata to perform yang mempunyai beberapa masukan (entries), yakni

(1) melakukan,

(2) memenuhi atau menjalankan suatu,

(3) melaksanakan suatu tanggung jawab,

(4) melakukan sesuatu yang diharapkan oleh seseorang.

Dari masukan tersebut dapat diartikan, kinerja adalah melakukan suatu kegiatan dan menyempurnakan pekerjaan tersebut sesuai dengan tanggung jawabnya sehingga dapat mencapai hasil sesuai dengan yang diharapkan. Widodo(2014:78) mengatakan bahwa :" kinerja adalah melakukan suatu kegiatan dan menyempurnakannya sesuai dengan tanggung jawabnya dengan hasil seperti yang diharapkan". Mangkunegara (2013:9) mengatakan bahwa:“ Kinerja adalah merupakan hasil kerja secara kualitas dan kuantitas yang dicapai oleh seseorang dalam melaksanakan fungsinya sesuai dengan tanggung jawab yang diberikan kepadanya. Beberapa pengertian tentang kinerja dalam Rivai dan Basri (2015:14) berikut ini dapat memperkaya wawasan adalah:

1. Kinerja merupakan seperangkat hasil yang dicapai dan merujuk pada tindakan pencapaian serta pelaksanaan sesuatu pekerjaan yang diminta.

2. Kinerja merupakan salah satu kumpulan total dari kerja yang ada pada diri pekerja.

3. Kinerja dipengaruhi oleh tujuan.

4. Kinerja merupakan suatu fungsi dari motivasi dan kemampuan. Untuk menyelesaikan tugas atau pekerjaan, seseorang harus memiliki derajat kesediaan dan tingkat kemampuan tertentu. Kesediaan dan keterampilan seseorang tidaklah cukup efektif untuk mengerjakan sesuatu tanpa pemahaman yang jelas tentang apa yang akandikerjakan dan bagaimana mengerjakannya.

5. Kinerja merujuk kepada pencapaian tujuan karyawan atas tugas yangdiberikan.

6. Kinerja merujuk kepada tingkat keberhasilan dalam melaksanakan tugas serta kemampuan untuk mencapai tujuan yang telah ditetapkan. Kinerja dinyatakan baik dan sukses jika tujuan yang diinginkan dapat tercapai dengan baik.

7. Pencapaian tujuan yang telah ditetapkan merupakan salah satu tolok ukur kinerja individu. Ada tiga kriteria dalam melakukan penilaian kinerja indivudu, yakni: (a) tugas individu; (b) perilaku individu; dan (c)ciri individu.

8. Kinerja sebagai kualitas dan kuantitas pencapaian tugas-tugas, baik yang dilakukan oleh individu, kelompok maupun perusahaan.

\section{Faktor-faktor Kinerja Pegawai}

Ada dua faktor utama yang mempengaruhi kinerja individu yakni kemampuan (ability), dan motivasi kerja (motivation) individu tersebut. Kemampuan individual tergantung dari tingkat pengetahuan (knowledge) yang dimiliki, latar 


\section{ENTREPRENEUR \\ Jurnal Bisnis Manajemen Dan Kewirausahaan \\ Program Studi Manajemen Fakultas Ekonomika dan Bisnis Universitas Majalengka \\ Published every January and July e-ISSN : 2776-2483, p-ISSN: 2723-1941 \\ Available online http://ejournal.unma.ac.id/index.php/entrepreneur}

belakang pendidikan, dan keterampilan (skill) yang dikuasai. Sedangkan motivasi kerja individual tergantung sikap (attitude) sebagai motivasi dasar dan lingkungan yang mempengaruhi motivasi tersebut. (Keith Davis dalam Mangkunegara, 2013:13).

\section{Faktor Kemampuan (Ability)}

Kapasitas individu untuk mengerjakan berbagai tugas dalam suatu pekerjaan tida sama satu dengan yang lainnya. Setiap manusia mempunyai kemampuan berpikir. Kemampuan (ability) merupakan kecakapan seseorang (kecerdasan dan keterampilan) dalam memecahkan persoalan.

Potensi tersebut selain merupakan bawaan lahir seseorang, juga dapat dipelajari dan oleh sebab itu memungkinkan untuk lebih dikembangkan/ditingkatkan.

Rivai dan Basri (2015:16) berpendapat bahwa kinerja individu pada dasarnya dipengaruhi oleh faktor-faktor:

(a) harapan mengenai imbalan;

(b) dorongan;

(c) kemampuan, kebutuhan dan sifat;

(d) persepsiterhadap tugas; (imbalan intenal dan eksternal); (f) persepsi terhadap tingkat imbalan dan kepuasan kerja.

Berdasarkan pendapat di atas yang mengemukakan keterkaitan antara kemampuan individu dengan kinerja pegawai bahwa sejauh mana seorang pegawai dapat mencapai hasil yang memuaskan dalam bekerja tergantung dari kemampuan dan kecakapannya.

\section{Motivasi}

Motivasi merupakan faktor dalam kompetensi yang dapat berubah. dengan memberikan dorongan, apresiasi terhadap pekerjaan bawahan, memberikan pengakuan dan perhatian individual dari atasan dapat mempunyai pegmnaruh positif terhadap motivasi seseorang bawahan.

\section{Kerangka Pemikiran}

Kompetensi sebagai kemampuan seseorang untukmenghasilkan pada tingkat yang memuaskan di tempat kerja, jugamenunjukkan karakteristik pengetahuan dan keterampilan yang dimilikiatau dibutuhkan oleh setiap individu yang memampukan mereka untukmelakukan tugas dan tanggung jawab mereka secara efektif dan meningkatkan standar kualitas professional dalam pekerjaan. Penilaian prestasi kerja yang efektif akan memberikan dampak yang positif bagi pengelolaan kinerja karyawan dalam suatu organisasi. Kapasitas individu untuk mengerjakan berbagai tugas dalam suatupekerjaan tida sama satu dengan yang lainnya. Setiap manusia mempunyai kemampuan berpikir. Kemampuan (ability) merupakan kecakapan seseorang (kecerdasan dan keterampilan) dalam memecahkan persoalan.

Dengan penilaian prestasi kerja yang efektif, organisasi dapat mengurangi konflik dalam pengelolaan kinerja. Untuk meningkatkan kinerja suatu organisasi harus mempunyai pegawai yang berkompetensi maksimal seperti pengetahuan yang luas, keterampilan. 


\section{ENTREPRENEUR}

\section{Jurnal Bisnis Manajemen Dan Kewirausahaan}

Program Studi Manajemen Fakultas Ekonomika dan Bisnis Universitas Majalengka

Published every January and July e-ISSN : 2776-2483, p-ISSN: 2723-1941

Available online http://ejournal.unma.ac.id/index.php/entrepreneur

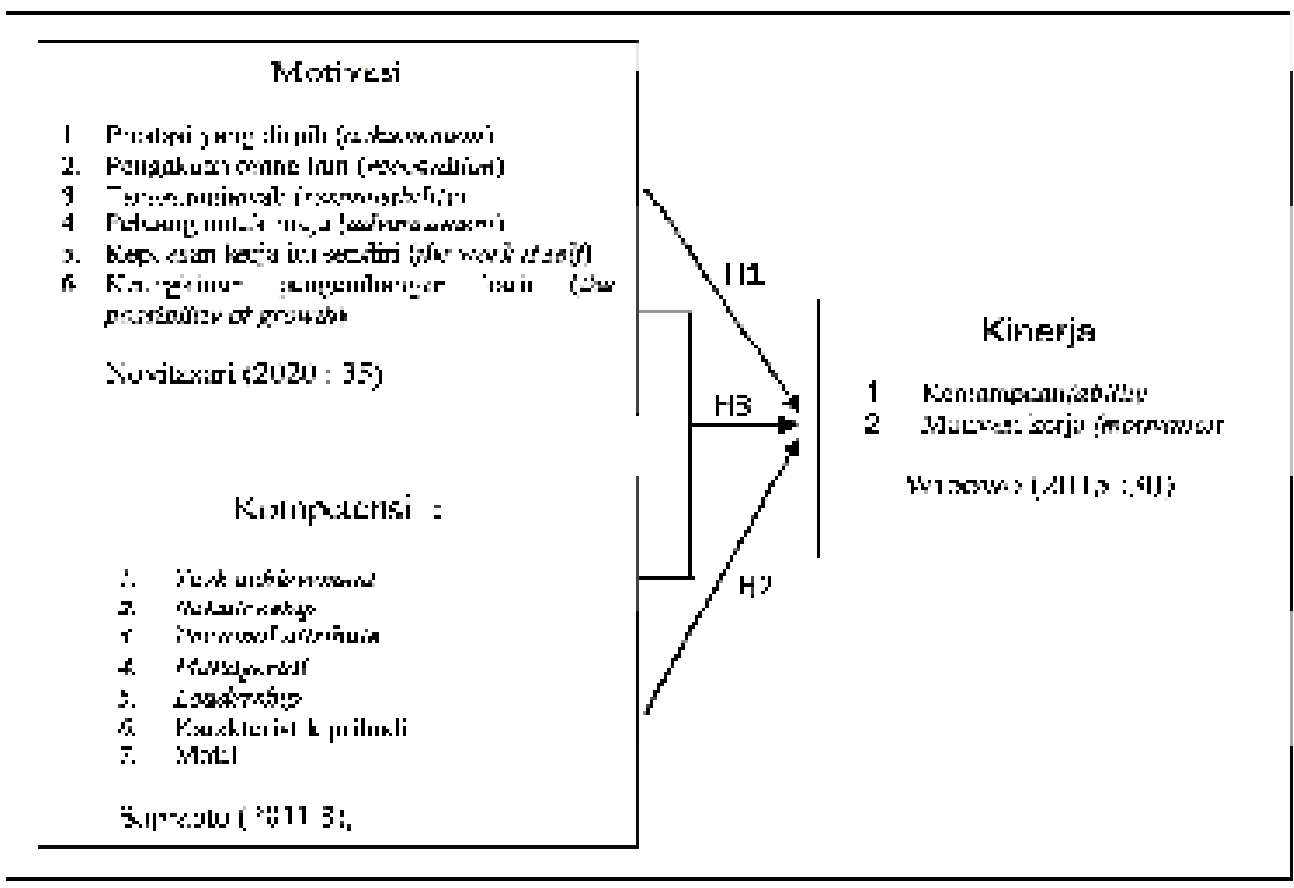

Gambar 1. Paradigma Penelitian

\section{Hipotesis}

Berdasarkan kerangka analisis yang telah dijelaskan, dirumuskan hipotesis penelitian sebagai berikut:

H1 : Diduga terdapat pengaruh Motivasi terhadap kinerja pegawai Rumah Sakit Umum Daerah Kabupaten sumedang.

H2 : Diduga terdapat pengaruh Kompetensi terhadap kinerja pegawai di Rumah Sakit Umum Daerah Kabupaten sumedang

H3 : Diduga terdapat pengaruh Motivasi dan Kompetensi terhadap terhadap kinerja pegawai pada Rumah Sakit Umum Daerah Kabupaten Sumedang

\section{METODELOGI PENELITIAN}

Penelitian ini dilakukan untuk mengetahui Pengaruh Motivasi dan Kompetensi terhadap Kineja pada Rumah Sakit Umum Daerah Kabupaten Sumedang secara simultan maupun parsial. Adapun yang menjadi objek penelitian sebagai variabel independen (variabel bebas) adalah Motivasi dan Kompetensi. Objek penelitian yang merupakan dependen variabel (variabel terikat) adalah Kinerja Pegawai di Instalasi Paviliun Tandang Rumah Sakit Umum Daerah Kabupaten Sumedang. Penelitian ini dilakukan untuk memperoleh Deskripsi tentang Motivasi, Kompetensi dan Kinerja perawat di Rumah Sakit Umum Daerah Kabupaten Sumedang. Jenis penelitian adalah deskriptif dan verifikatif, penelitian deskriptif bertujuan untuk memperoleh secara jelas tentang suatu situasi atau keadaan tertentu. Metode Deskriptif merupakan metode yang ditujukan untuk memecahkan masalah yang terjadi pada masa sekarang.Definisi operasional, indikator dan pengukuran terhadap variabel yang telah ditetapkan 


\section{ENTREPRENEUR \\ Jurnal Bisnis Manajemen Dan Kewirausahaan \\ Program Studi Manajemen Fakultas Ekonomika dan Bisnis Universitas Majalengka \\ Published every January and July e-ISSN : 2776-2483, p-ISSN: 2723-1941 \\ Available online http://ejournal.unma.ac.id/index.php/entrepreneur}

dalam penelitian ini meliputi Kompetensi (X1), Motivasi (X2) dan kinerja pegawai (Y), dengan masing-masing sub variabel sebagai berikut :

\section{Motivasi (X1)}

Faktor pemuas yang disebut juga motivator yang merupakan faktor pendorong seseorang untuk berprestasi yang bersumber dari dalam diri seseorang tersebut (kondisi intrinsik) menurut Novitasari (2020 : 35) antara lain:

1. Prestasi yang diraih (achievement)

2. Pengakuan orang lain (recognition)

3. Tanggungjawab (responsibility)

4. Peluang untuk maju (advancement)

5. Kepuasan kerja itu sendiri (the work it self)

6. Kemungkinan pengembangan karir (the possibility of growth)

\section{Kompetensi (X2)}

Suprapto (2011:3), Lima karakteristik yang membentuk kompetensi, sebagai berikut:

1. Task achievement merupakan kategori kompetensi yang berhubungan dengan kinerja baik.

2. Relationship merupakan kategori kompetensi yang berhubungan dengan komunikasi dan bekerja baik dengan orang lain dan memuaskan kebutuhannya.

3. Personal attribute merupakan kompetensi intrinsic individu dan menghubungkan bagaimana orang berpikir, merasa, belajar dan berkembang.

4. Managerial merupakan kompetensi yang secara spesifik berkaitan dengan pengelolaan, pengawasan dan mengembangkan orang. Kompetensi manajerial berupa: memotivasi, memberdayakan, dan mengembangkan orang lain.
5. Leadership merupakan kompetensi yang berhubungan dengan memimpin organisasi dan orang untuk mencapai maksud, visi, dan tujuan organisasi.

6. Karakteristik pribadi; merujuk pada karakteristik fisik dan konsistensi tanggapan terhadap situasi atau informasi, seperti pengendalian diri dan kemampuan untuk tetap tenang dibawah tekanan.

7. Motif; merupakan emosi, hasrat, kebutuhan psikologis atau dorongandorongan lain yang memicu tindakan.

Kinerja (Y)

Indikator Kinerja menurut Wibowo (2015

1. Kemampuan(ability),

Kemampuan individual tergantung dari tingkat pengetahuan (knowledge) yang dimiliki, latar belakang pendidikan, dan keterampilan (skill) yang dikuasai

2. Motivasi kerja (motivation) individu tersebut sedangkan motivasi kerja individual tergantung sikap (attitude) sebagai motivasi dasar dan lingkungan yang mempengaruhi motivasi tersebut.

Data penelitian terdiri dari dua macam, yaitu ; data primer; sumber data primer adalah hasil wawancara atau hasil pengisian kuisioner yang biasa dilakukan oleh peneliti. Data sekunder; data sekunder adalah sumber-sumber seperti artikel, internet, jurnal, dan bacaan yang berhubungan dengan pebelitian ini. Adapun metode pengumpulan data yang digunakan dalam penelitian ini adalah angket (Questionnaire); metode ini yang dilakukan dengan mengajukan daftar pertanyaan secara tertulis kepada responden yang diinginkan untuk dijawab.Wawancara; metode pengumpulan data dengan melakukan wawancara dengan beberapa sumber informasi dilapangan.Studi pustaka; metode pengumpulan data dengan menggunakan buku atau literatur yang 


\section{ENTREPRENEUR}

\section{Jurnal Bisnis Manajemen Dan Kewirausahaan}

Program Studi Manajemen Fakultas Ekonomika dan Bisnis Universitas Majalengka

Published every January and July e-ISSN : 2776-2483, p-ISSN: 2723-1941

Available online http://ejournal.unma.ac.id/index.php/entrepreneur

berkaitan dengan penelitian yang dilakukan. Penarikan sampel dalam penelitian ini menggunakan sensus yaitu merupakan kegiatan pengambilan data dengan mengambil langsung dari totalitas elemen populasi. Rully dan Poppy (2014 ; 93). Berdasarkan data yang diperoleh dari Rumah Sakit Umum Daerah Sumedang terdapat 42 pegawai yang berada di Instalasi Paviliun Tandang Rumah Sakit Umum Sumedang.

\section{Metode analisis Data}

Analisis jalur merupakan bagian dari analisis regresi yang digunakan untuk menganalisis hubungan kausal antar variable dimana variabel-variabel bebas mempengaruhi variabel tergantung, baik secara langsung maupun tidak langsung, melalui satu atau lebih perantara (Rully \& Popy, 2014:147). Untuk menganalisis hubungan kausal atar variabel dan menguji hipotesis dalam penelitian ini secara sistematis, maka alat analisis yang digunakan yaitu analisis jalur (Path Analysis) dengan menggunakan software SPSS 16 for Windows. Dengan Path Analysis akan dilakukan estimasi pengaruh kausal antar variabel dan kedudukan masing-masing variabel dalam jalur baik secara langsung maupun tidak langsung. Signifikan model tampak berdasarkan koefisien beta $(\beta)$ yang signifikan terhadap Pengujian hipotesis dengan menggunakan uji $\mathrm{t}$ digunakan melihat signifikansi pengaruh dari variabel bebas (X) secara parsial (individu) terhadap variabel terikat (Y), (Sugiono, 2008:84). Keputusan untuk menolak atau menerima Ho dilakukan dengan membandingkan nilai thitung $(\mathrm{t}=$ thitung; $\mathrm{bi}=$ bobot regresi, $\mathrm{Sbi}=$ standart deviasi dari variabel bebas)

\section{PEMBAHASAN \\ Motivasi kerja perawat Paviliun Tandang pada Rumah Sakit Umum Daerah Kabupaten Sumedang}

Pentingnya motivasi karena motivasi adalah hal yang menyebabkan, menyalurkan dan mendukung prilaku manusia, upaya mau bekerja giat dan antusias mencapai hasil yang optimal.Organsiasi bukan saja mengharapkan pegawai yang mampu, cakap dan terampil dalam bekerja, hal yang juga penting ialah mereka mau bekerja dengan giat dan memiliki keinginan untuk mencapai hasil yang maksimal.

Banyak cara organisasi untuk memotivasi para pegawai diantaranya adalah memberikan upah yang adil dan layak, kesempatan untuk maju/promosi, pengakuan pegawai sebagai individu, menciptakan rasa aman dalam bekerja tempat kerja yang baik, perasaan diterima oleh kelompok, perlakuan yang wajar dan pengakuan atau prestasi. Berdasarkan pada hasil penyebaran kuisioner terlihat variabel motivasi berada pada kategori Baik setiap indikatornya, indikator yang terkecil atau terndah ada pada indikator kemampuan mengembangkan kemampuan dan membina rekan kerja dan bawahan sehingga indikator ini harus ditindaklanjuti oleh Paviliun Tandang Rumah Sakit Umum Daerah Kabupaten Sumedang, sedangkan yang tertinggi adalah ada pada indikator Mampu menentukan dan mengatur prioritas kerja secara efektif. Dengan demikian maka perawat pada Paviliun Tandang sangat memperhatikan pekerjaan mereka dan selalu memprioritaskan apa yang menjadi tanggung jawabnya sendiri. Sedangkan kemampuan dan membina rekan kerja dan bawahan masih kurang sehingga perlu mendapat perhatian dari pihak organisasi. 


\section{ENTREPRENEUR \\ Jurnal Bisnis Manajemen Dan Kewirausahaan \\ Program Studi Manajemen Fakultas Ekonomika dan Bisnis Universitas Majalengka \\ Published every January and July e-ISSN : 2776-2483, p-ISSN: 2723-1941 \\ Available online http://ejournal.unma.ac.id/index.php/entrepreneur}

Berdasarkan hasil penyebaran kuisioner terlihat bahwa indikator perhatian pada aspek detail, akurasi, kecermatan dan ketelitian dalam bekerja berada pada kategori Sangat Tinggi, hal itu berarti kualitas kerja perawat sudah optimal karena mereka bekerja dengan teliti dan cermat sehingga memperkecil kesalahan dalam menangani pasien. Indikator yang terendah berada pada skor 127 dengan kategori Cukup tinggi yaitu dengan indikator menggunakan sebagian waktunya untuk memikirkan tentang apa yang orang lain pikir dan rasakan, berarti perawat masih kurang toleransi kepada rekan kerja sehingga kurang memperdulikan tentang apa yang orang lain pikir dan rasakan.

Dari data hasil tanggapan responden yang mendapatkan skor tertinggi pada indikator mampu membuat keputusan yang berhubungan dengan pekerjaan. mengembangkan solusi alternative dan rekomendasi serta memilih tindakan yang tepat dalam menunjang proses pelaksanaan tugas dan tanggungjawabnya, berarti perawat di Paviliun Tandang Rumah Sakit Umum Daerah Kabupaten Sumedang terlihat sudah mampu memcahkan masalah yang berkaitan dengan pekerjaanya terutama permasalahan yang berhubungan dengan pasien, dalam memecahkan masalahan perawat di perlukan pemilihan alternative untuk mencari solusi yang terbaik.

Sedangkan indikator yang terkecil ada pada Senantiasa mematuhi peraturan dan prosedur kesehatan dan keselamatan kerja, berarti perawat di Pavilun Tandang kurang memperhatikan keselamatan kerja padalah keselamatan kerja merupakan hal yang penting dan harus diperhatikan oleh suatu organisasi karena keselamtan kerja merupakan suatu sitem yang bertujuan melakukan pencegahan terhadap kemungkinan timbulnya kecelakaan yang diakibatkan oleh hubungan kerja di dalam lingkungan kerja. Pada indikator ini rumah Sakit harus lebih memperhatikan keselamatan kerja perawat.

Kemudian indikator yang terkecil selanjutnya adalah Memahami segala konsekuensi keputusan dan tindakan yang diambil, berarti indikator ini perlu diperhatikan oleh Rumah Sakit karena perawat masih kurang memahami atas konsekuensi atas tindakannya masih kurang mempertimbangkan dan memperhitungkan tindakan terhadap pasien.

\section{Pengaruh Motivasi kerja terhadap Kinerja Perawat}

Untuk melihat apakah ada pengaruh antara variabel Motivasi dan kinerja perawat, hal perlu dilakukan adalah menentukan hipotesis sebagai berikut:

Berdasarkan hasil perhitungan diperoleh $\mathrm{t}$ hitung $6.842>$ dari $\mathrm{t}$ tabel 2.011, maka H0 ditolak dan $\mathrm{H} 1$ diterima. Artinya terdapat pengaruh antara Motivasi dan kinerja perawat. Sedangkan besarnya pengaruh Motivasi terhadap kinerja Perawat sebesar 0.530 atau 53\%. Artinya Motivasi naik, maka kinerja akan meningkat.

\section{Pengaruh Kompetensi terhadap Kinerja Perawat}

Untuk melihat apakah ada pengaruh antara variabel Kompetensi dan kinerja Perawat, hal perlu dilakukan adalah menentukan hipotesis sebagai berikut:

Berdasarkan hasil perhitungan diperoleh $\mathrm{t}$ hitung $6.034>$ dari $\mathrm{t}$ tabel 2.011, maka H0 ditolak dan $\mathrm{H} 1$ diterima. Artinya terdapat pengaruh antara Kompetensi dan kinerja Perawat. Sedangkan besarnya pengaruh Kompetensi dan kinerja Perawat sebesar 0.468 atau $46.8 \%$. 


\begin{tabular}{|c|c|}
\hline $\begin{array}{r}\text { ENTR } \\
\text { Jurnal Bisnis Mana } \\
\text { Program Studi Manajemen Fakultas } \\
\text { Published every January and } \\
\text { Available online http://ejo }\end{array}$ & $\begin{array}{l}\text { VEUR } \\
\text { an Kewirausahaan } \\
\text { dan Bisnis Universitas Majalengka } \\
\text { 776-2483, p-ISSN: 2723-1941 } \\
\text { id/index.php/entrepreneur }\end{array}$ \\
\hline 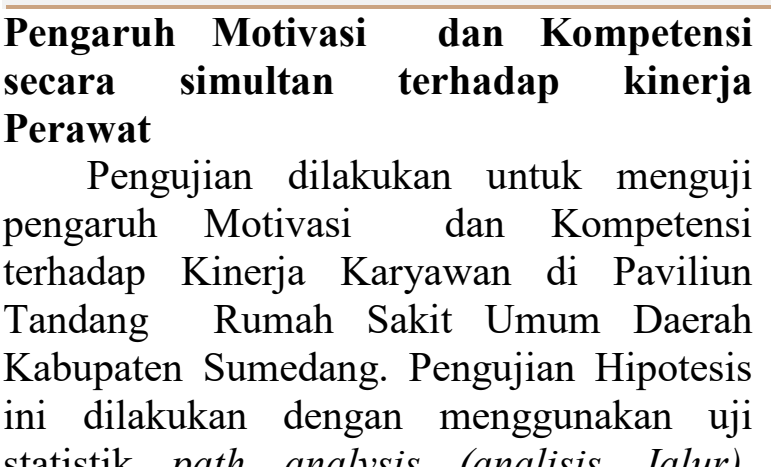 & $\begin{array}{l}\text { Kompetensi sebagai variabel sebab } \\
\text { (eksogenus variabel) dan variabel kinerja } \\
\text { perawat sebagai variabel akibat (edogenus } \\
\text { variabel). Untuk melihat apakah model } \\
\text { regresi sudah tepat atau tidak, yaitu dengan } \\
\text { menguji cara mgnuji hipotesis dengan } \\
\text { menggunakan uji F, atau dengan } \\
\text { membandingkan taraf signifikansi (sig) pda } \\
\text { tabel ANOVA. }\end{array}$ \\
\hline
\end{tabular}

Dalam penelitian ini variabel Motivasi dan

Tabel 2. ANOVA

\begin{tabular}{llrrrrr}
\hline Model & & $\begin{array}{c}\text { Sum of } \\
\text { Squares }\end{array}$ & df & $\begin{array}{c}\text { Mean } \\
\text { Square }\end{array}$ & F & Sig \\
\hline 1 & Regression & 1933.292 & 2 & 966.646 & 326.175 & $.000(\mathrm{a})$ \\
& Residual & 139.288 & 40 & 2.964 & & \\
& Total; & 2072.580 & 42 & & & \\
\hline
\end{tabular}

a. Predictors: (Constant), motivasi kerja , Kompetensi

b. Dependent Variable: kinerja Perawat

Sumber: Data diolah

Berdasarkan hasil perhitungan diperoleh angka $\mathrm{F}$ hitung sebesar $326.175>$ $\mathrm{F}$ tabel 3.20, maka $\mathrm{H} 0$ ditolak dan $\mathrm{H} 1$ diterima. Artinya ada hubungan linier antara Motivasi dan Kompetensi terhadap kinerja perawat. Dengan demikian model regresi tersebut sudah layak dan benar. Untuk melihat pengaruh Motivasi dan Kompetensi terhadap kinerja Perawat secara simultan (gabungan) dapat dilihat melalui tabel model summary berikut ini:

Tabel 3. Model Summary

\begin{tabular}{ccccc}
\hline Model & R & R Squares & $\begin{array}{c}\text { Adjusted } \\
\text { R Square }\end{array}$ & $\begin{array}{c}\text { Std.Error of the } \\
\text { Estimate }\end{array}$ \\
\hline 1 & .966 & .933 & .930 & 1.722
\end{tabular}

Predictors: (Constant), motivasi kerja karyawan, Kompetensi Sumber: Data diolah

Tabel diatas menunjukkan bahwa besarnya $\mathrm{R}$ Square adalah 0.933 , angka ini dapat digunakan untuk melihat besarnya pengaruh Motivasi dan Kompetensi terhadap kinerja perawat secara bersamasama atau simultan dengan cara menghitung
Koefisien Determinan (KD) dengan menggunakan rumus berikut:

$$
\begin{aligned}
\mathrm{KD} & =\mathrm{R}^{2} \times 100 \% \\
\mathrm{KD} & =93.3 \%
\end{aligned}
$$

Hal ini menunjukkan bahwa besarnya pengaruh Motivasi dan Kompetensi terhadap kinerja Perawat secara bersama- 


\section{ENTREPRENEUR \\ Jurnal Bisnis Manajemen Dan Kewirausahaan \\ Program Studi Manajemen Fakultas Ekonomika dan Bisnis Universitas Majalengka \\ Published every January and July e-ISSN : 2776-2483, p-ISSN: 2723-1941 \\ Available online http://ejournal.unma.ac.id/index.php/entrepreneur}

sama adalah sebesar $93.3 \%$ sedangkan sisanya sebesar $6.7 \%$ dipengaruhi faktor lain, yaitu, Pelatihan, Kompensasi dan lainlain.

\section{Pengaruh Motivasi dan Kompetensi secara parsial terhadap Kinerja}

Tabel 4. Coefficients

\begin{tabular}{|l|c|c|c|c|c|}
\hline \multirow{2}{*}{ Model } & \multicolumn{2}{|c|}{$\begin{array}{c}\text { Unstandardized } \\
\text { Coefficients }\end{array}$} & $\begin{array}{c}\text { Standardized } \\
\text { Coefficients } \\
\text { Beta }\end{array}$ & \multirow{2}{*}{$\mathrm{t}$} & \multirow{2}{*}{ Sig } \\
\cline { 2 - 5 } & $\mathrm{B}$ & $\begin{array}{c}\text { Std } \\
\text { Error }\end{array}$ & & & \\
\hline Motivasi & .772 & 1.893 & 530 & .408 & .685 \\
Kompetensi & .701 & .102 & & 6.842 & .000 \\
Kinerja & 334 & 055 & 468 & 6.034 & .000 \\
\hline
\end{tabular}

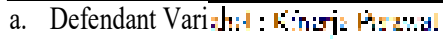

Untuk melihat besarnya pengaruh variabel Motivasi dan Kompetensi terhadap kinerja Perawat secara parsial. Digunakan uji t, sedangkan untuk melihat besarnya pengaruh digunakan, angka $\beta$ (beta) atau standardized coefficient di bawah ini.

Tabel 5. Korelasi antara variabel

\begin{tabular}{|c|c|c|c|}
\hline & & Motivasi & Kompetensi \\
\hline \multirow[t]{3}{*}{ Motivasi } & Pearson Correlation & 1 & .873 \\
\hline & Sig. (2-tailed) & 40 & .000 \\
\hline & $\mathrm{N}$ & .873 & 1 \\
\hline \multirow[t]{3}{*}{ Kompetensi } & Pearson Correlation & .000 & \\
\hline & Sig. (2-tailed) & 42 & 42 \\
\hline & $\mathrm{N}$ & & \\
\hline
\end{tabular}

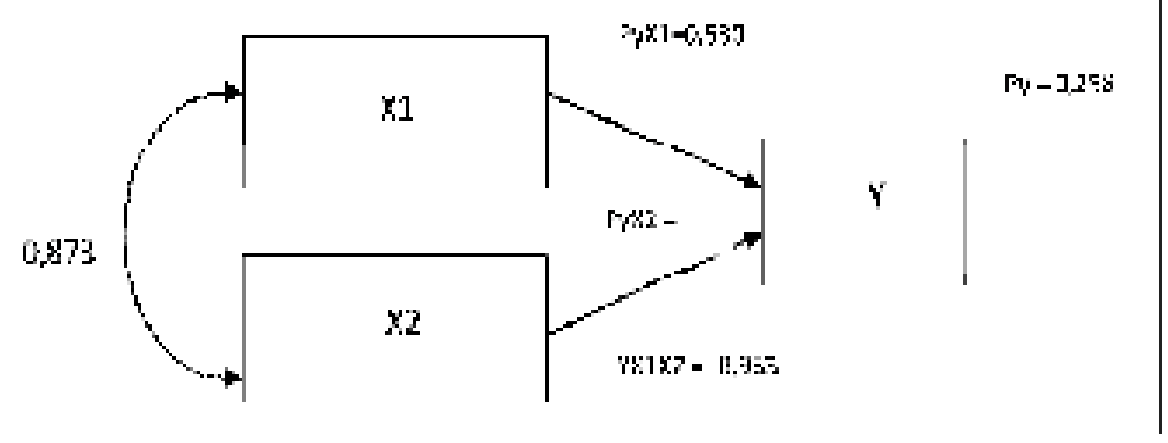

Gumbur 4,1

Diagram Jular pergarmh XI dav X2 tertadap $\gamma$

Berdasarkan hasil perhitungan diketahui nilai korelasi antar variabel Motivasi dan Kompetensi adalah 0.873. Terlihat hubungan antar variabel sangat kuat. Dan korelasi kedua variabel bersifat signifikansi $0.000<0.05$. Dari hasil perhitungan koefisien jalur yang diperoleh, maka dapat terlihat besarnya pengaruh variabel yang dihipotesiskan. Sehingga dapat digambarkan hubungan pengaruh X1 dan X2 terhadap Y seperti di atas.
Dengan memperhatikan tabel dan gambar di atas, maka diperoleh persamaan strukturalnya sebagai berikut :

$\mathrm{Y}=0,530 \mathrm{X} 1+\mathbf{0 . 4 6 8} \mathrm{X} 2+\mathbf{0 . 2 5 8 \varepsilon}$

Angka koefisien residu sebesar 0.258 berasal dari $\sqrt{ }(1-R 2)$ yang berarti $\sqrt{ }(1-$ $0.933)=0.258$. artinya variabel-variabel yang di luar variabel penelitian mempengaruhi terhadap Kinerja Perawat.

Pengaruh motivasi dan kompetensi secara simultan terhadap kinerja Perawat, untuk melihat pengaruh motivasi dan 


\section{ENTREPRENEUR \\ Jurnal Bisnis Manajemen Dan Kewirausahaan \\ Program Studi Manajemen Fakultas Ekonomika dan Bisnis Universitas Majalengka \\ Published every January and July e-ISSN : 2776-2483, p-ISSN: 2723-1941 \\ Available online http://ejournal.unma.ac.id/index.php/entrepreneur}

kompetensi terhadap kinerja Perawat secara simultan (gabungan), besarnya $\mathrm{R}$ Square dapat digunakan untuk melihat besarnya pengaruh motivasi dan kompetensi terhadap kinerja perawat secara bersamasama atau simultan. Besarnya pengaruh motivasi dan kompetensi terhadap kinerja Perawat secara bersama-sama dipengaruhi faktor lain, yaitu, pelatihan, kompensasi dan lain-lain.

\section{SIMPULAN DAN IMPLIKASI}

\section{Simpulan}

1. Pengaruh Motivasi terhadap Kinerja Perawat, hasil penelitian diperoleh variabel motivasi berada pada kategori Baik setiap indikatornya Dengan demikian maka perawat pada Paviliun Tandang sangat memperhatikan pekerjaan mereka dan selalu memprioritaskan apa yang menjadi tanggung jawabnya sendiri. Sedangkan kemampuan dan membina rekan kerja dan bawahan masih kurang sehingga perlu mendapat perhatian dari pihak organisasi. Berdasarkan hasil perhitungan diperoleh terdapat pengaruh antara Motivasi dan kinerja perawat. Sedangkan besarnya pengaruh Motivasi terhadap kinerja Perawat mengandung arti bahwa jika Motivasi naik, maka kinerja akan meningkat.

2. Pengaruh Kompetensi terhadap Kinerja, berdasarkan penelitian bahwa indikator perhatian pada aspek detail, akurasi, kecermatan dan ketelitian dalam bekerja berada pada kategori Sangat Tinggi, hal itu berarti kualitas kerja perawat sudah optimal karena mereka bekerja dengan teliti dan cermat sehingga memperkecil kesalahan dalam menangani pasien. Indikator yang terendah berada indikator menggunakan sebagian waktunya untuk memikirkan tentang apa yang orang lain pikir dan rasakan, berarti perawat masih kurang toleransi kepada rekan kerja sehingga kurang memperdulikan tentang apa yang orang lain pikir dan rasakan. Berdasarkan hasil perhitungan diperoleh terdapat pengaruh antara Kompetensi dan kinerja Perawat.

3. Pengaruh Motivasi dan Kompetensi terhadap Kinerja perawat di Paviliun Tandang Rumah Sakit Umum Daerah Kabupaten Sumedang, Hasil perhitungan diperoleh terdapat pengaruh Motivasi dan Kompetensi terhadap kinerja Perawat secara bersama-sama sedangkan faktor lain, yaitu, Pelatihan, Kompensasi dan lain-lain ikut mempengaruhi kinerja. hubungan antar variabel sangat kuat.

4. Motivasi terhadap Kinerja Perawat di Paviliun Tandang Rumah Sakit Umum Daerah Kabupaten Sumedang mempunyai pengaruh langsung tanpa memperhatikan Kompetensi Peningkatan Kinerja Perawat dipengaruhi oleh peningkatan Motivasi perawat di Paviliun Tandang Rumah Sakit Umum Daerah Kabupaten Sumedang, dan terdapat pengaruh langsung Kompetensi terhadap kinerja Perawat tanpa memperhatikan Motivasi dan pengaruh tidak langsung Kompetensi terhadap kinerja Perawat Paviliun Tandang Rumah dengan demikian peningkatan kinerja perawat dipengaruhi oleh peningkatan kompetensi Perawat Paviliun Tandang Rumah Sakit Umum Daerah Kabupaten Sumedang.

5. Motivasi dan Kompetensi secara bersama mempunyai pengaruh secara langsung terhadap kinerja Perawat di Paviliun Tandang Rumah Sakit Umum Daerah Sumedang diperoleh pengaruh Motivasi dan Kompetensi secara bersama baik pengaruh langsung maupun tidak langsung terhadap Kinerja Perawat. 


\section{ENTREPRENEUR}

\section{Jurnal Bisnis Manajemen Dan Kewirausahaan}

Program Studi Manajemen Fakultas Ekonomika dan Bisnis Universitas Majalengka

Published every January and July e-ISSN : 2776-2483, p-ISSN: 2723-1941

Available online http://ejournal.unma.ac.id/index.php/entrepreneur

Dengan demikian diperoleh bahwa variabel yang memiliki pengaruh terbesar terhadap Kinerja Perawat Rumah Sakit Umum Daerah Kabupaten Sumedang adalah variabel Motivasi.

\section{Implikasi}

1. Kinerja Perawat di Paviliun Tandang Rumah Sakit Umum Daerah Kabupaten Sumedang baik, maka organisasi harus terus memperhatikan para pegawainya, dengan mempertahankan atau bahkan meningkatkan kemampuan dan motivasi kerja karyawannya. Karena berdasarkan hasil penelitian, kedua faktor ini sangat mempengaruhi kinerja pegawai Rumah Sakit Umum Daerah Kabupaten Sumedang.

2. Perawat di Paviliun Tandang Rumah Sakit Umum Daerah Kabupaten Sumedang seharusnya senantiasa mematuhi peraturan dan prosedur kesehatan dan keselamatan kerja, karena keselamtan kerja merupakan suatu sitem yang bertujuan melakukan pencegahan terhadap kemungkinan timbulnya kecelakaan yang diakibatkan oleh hubungan kerja di dalam lingkungan kerja.

3. Perawat di Paviliun Tandang harus lebih meningkatkan kemampuan terutama kemampuan dan membina rekan kerja dan bawahan, saling memberikan dorongan dan semangat sehingga kinerja perawat bisa lebih meningkat.

\section{DAFTAR PUSTAKA}

Hasibuan, Malayu S.P. 2019. Manajemen Sumber Daya Manusia (Edisi Revisi). Bumi Aksara. Jakarta.

Prabu Anwar. 2013. Evaluasi Kinerja SDM. Refika Aditama. Bandung.
Marwansyah.2014.Manajemen

Sumber Daya Manusia. Alfabeta. Bandung

Mitrani, Alain. 2005. Manajemen Sumber Daya Manusia Berbasis Kompetensi (terjemahan). PT. Intermasa. Jakarta.

Murgiyono. 2012. Kompetensi Dasar PNS, Konsep Pemikiran Manajemen SDM PNS Berbasis Kompetensi. Jakarta.

Mustopadidjaja A.R. 2003. Manajemen Proses Kebijakan Publik, Formulasi,Implementasi, dan Evaluasi Kinerja. LAN RI. Jakarta.

Palan, R. 2007. Competency Management. Teknik Mengimplementasikan Manajemen SDM berbasis Kompetensi untuk Meningkatkan Daya Saing Organisasi. Penerjemah: Octa Melia Jalal. Penerbit PPM. Jakarta.

Prayitno, Widodo dan Suprapto. 2002. Standarisasi Kompetensi Pegawai Negeri Sipil Menuju Era Globalisasi Global. Seri Kertas Kerja VolumeII Nomor 05. Pusat Penelitian dan Pengembangan BKN. Jakarta.

Rivai, Basri. 2005. Performance Appraisal. PT. Raja Grafindo Persada. Jakarta.

Robbins, P. Stephen. 2014. Teori Organisasi: Struktur, Disain \& Aplikasi. Terjemahan. Arcan, Jakarta.

Rully dan Poppy. 2014. Metodologi penelitian. Kuantitatif, kualitatif dan Campuran untuk Manajemen, Pembangunan dan Pendidikan. Edisi Revisi. Refika Aditama. Bandung.

Sugiyono. 2001. Metode Penelitian Administrasi. Alfabeta. Bandung.

Sugiyono,2006. Metode Penelitian Administrasi (Edisi Revisi). Alfabeta. Bandung.

Wibowo, 2015. Manajemen Kinerja, edisi keempat. Jakarta: PT. Raja Grafindo Persada. 